\title{
Review of Wheat Value Chain in Ethiopia
}

\author{
Tigist Zewdu* \\ Department of Agribusiness and value chain management, P.O.Box 193, \\ Arsi University, Asella, Ethiopia \\ Samuel Lindi \\ Kulumsa Agricultural Research Center, P.O.Box 489, Asella, Ethiopia
}

\begin{abstract}
In Ethiopia, agriculture contributes over 35.8 percent to the national gross domestic product (GDP), almost 90 percent of export and 72.7percent of employment. Wheat production in 2020 for Ethiopia was 5,100 thousand tons. Ethiopia is the second largest wheat producers in Sub Saharan Africa next to South Africa, with a potential expansion to 1.3 million hectare. The objective of this review is to identify wheat value chain the key actors and their roles in wheat value chain and challenges and opportunities of wheat value chain in Ethiopia. The main actors in the chain include producers, processor, assembler, wholesaler, retailers, and consumers whereas the indirect actors are financial institutions, governments, NGOs). Marketing channel is a business structure of interdependent organizations involved in the process of making the product or service available for consumption starting from product origin. In terms of regional production potential Oromia contributes (57\%), Amhara (28\%), SNNP (8.7\%) and Tigray (6.2\%). These show that there is a weak linkage among the wheat value chain actors in Ethiopia. One of the indicators for this weak linkage is the absence (very low level) of linkage between producers and millers few of the wheat produced is directly sold to millers.
\end{abstract}

Keywords: Value Chain, Wheat, Ethiopia

DOI: $10.7176 / \mathrm{JAAS} / 77-03$

Publication date: January $31^{\text {st }} 2022$

\section{Introduction}

In Ethiopia, agriculture contributes over 35.8 percent to the national gross domestic product (GDP), almost 90 percent of export and 72.7percent of employment (CSA, 2018). Agriculture is a key to Africa's future. The continent has most of the world's arable land, and over half of the population is employed under the agricultural sector and it is the largest contributor to the total gross domestic product (GDP). Yet, still Africa is producing too little food and low value- added products, and productivity has been broadly stagnant since the 1980s (AGRA, 2018).

The most important crops in Ethiopian agriculture are cereals such as wheat, barley, maize, sorghum, and teff (GAIN, 2014). Cereal production and marketing provide a source of income for millions of smallholder households, accounting for 60 percentland an average productivity of rural employment, 80 percent of total cultivated land, over 40 percent of typical household food expenditures, and more than 60 percent of total caloric intake (CSA, 2017).

World Data Atlas reported, in 2020, wheat production for Ethiopia was 5,100 thousand tons. Before wheat production of Ethiopia started to increase to reach a level of 5,100 thousand tons in 2020, it went through a trough reaching a low of 429 thousand tons in 1977. The nation's wheat production is estimated at 4.6 million tons, up from 4.5 million tons in the previous year.

Wheat (Triticum aestivum L.) is one of the globally produced and marketed cereal crops, which covers $15 \%$ of the total sowing areas of cereal crops in the world. It is an important industrial and food grain, which ranks second among the most important cereal crops in the world, after rice and traded internationally (FAO, 2009, Najafi, A. 2014 and Falola, et al 2017).

Wheat is one of the important cereal crops consumed in different forms in Ethiopia and the rest of the world. Ethiopia is the second largest wheat producer in sub-Saharan Africa (SSA) next to South Africa (Abu, 2012; Demeke and Marcantonio, 2013). The crop ranked fourth after tef, maize and sorghum both in terms of area coverage $(1,663,845.63$ hectares) and quantity of production (4,231,588.72 tons) in 2014/15cropping season in Ethiopia (CSA, 2015). Four major wheat producing regions in Ethiopia, namely Oromia, Amhara, SNNP, and Tigray account for about $99 \%$ of national wheat production sharing $58 \%, 28 \%, 8 \%$ and $5 \%$ in $2014 / 15$ cropping season, respectively (CSA, 2015).

Even though Ethiopia is one of the top ranking producers of wheat in Africa, it is not yet self-sufficient because of huge population and the consequent growth of demand. The FAOSTAT data of half a century indicates that the wheat self-sufficiency ratio of the country has declined from $99 \%$ in the 1960 s to $70 \%$ in 2000 s. This is due to the fast growth rate of domestic consumption resulted from population growth and urbanization. As a result, the country has been importing wheat for several decades. For instance, Ethiopia imported about 
900,000 tons of wheat grain to satisfy its demands of 5,250,000 tons for domestic utilization (for food, industrial use, seed, and feed consumption) in 2014 (USDA, 2014).

In addition to the wheat grain, the country has also been importing wheat flour although it is very low compared to the wheat grain import. The FAOSTAT data of fifteen years (1999-2013) shows that the wheat flour (in wheat grain equivalent) imports is about $2.01 \%$ of the total wheat grain imported during the same period. Therefore, filling the huge gap of supply and demand in the wheat sector needs a strategic approach. One of these strategies is employing a value chain approach in the wheat sector. The value chain approach involves identification and assessment of the whole range of actors involved and activities ranging from input supply to final utilization

It could include operations such as improved wheat variety generation, seed and supply of other inputs, production, marketing, and processing and consumption segments. It also investigates supporting and enabling environments at each segment of the chain to understand the interwoven problems in the wheat subsector. The objectives of this review were to review wheat value chain actors and review challenges and opportunities of wheat value chain in Ethiopia.

\section{Literature Review}

\subsection{Value Chain and Marketing Concept of the Ethiopian wheat Sector \\ 2.1.1. Wheat Value chain}

Since Ethiopia's market liberalization in the early 1990s many studies (Gebre-Madhin, 2004; Mohammed, 2009; Demeke and Marcantonio, 2013) have been conducted on commodity market performance and value chain analysis for key agricultural commodities, such as for wheat, in Ethiopia. The development of stable and reliable marketing system has been an important element to enhance productivity and commercialization of smallholder cereal producers. With nearly half of the Ethiopian population depending on the food grain market (GebreMadhin, 2004), the performance of the domestic market is vital for food security and economic growth in the country.

The main actors in the value chain are smallholder farmers who tend to sell large quantities of their production during and soon after the main (meher) harvest, but further sales may occur as they off- load grain stocks to avoid damage and loss caused by storage pests (Walker and Wandschneider, 2005). The wheat farmers can either sell the grain to wholesalers or trade small quantities to rural assemblers.

\subsubsection{Wheat Marketing}

Wheat is produced mainly for consumption in Ethiopia and its trend is increasing. Besides its consumption, it also used for markets; it contributes to $80 \%$ of the total marketed quantity of cereal production; there is a large demand-supply gap. Smallholder farmers market their wheat produce only $20 \%$ of production and $80 \%$ of their total production are used for consumption; the per capital share of quantity consumed in pastoral areas, humid low highlands, small and large cities are $20 \%, 1 \%, 6 \%$ and $9 \%$ of all food consumptions respectively Dubale A., 2018 cited (World Bank, 2012, Berhane et al., 2011; FAO, 2013; USDA, 2013).

\subsection{Wheat producers, production and productivity in Ethiopia}

\subsubsection{Wheat producers in Ethiopia}

Ethiopian agriculture is dominated by smallholders. As of 2014, close to 5 million wheat farmers engage in wheat production in Ethiopia. This is about a third of all smallholder farmers in the country (CSA, 2014). Despite their vast number, Ethiopian farmers in general cultivate small plots/acreage. Above half of the smallholders cultivate farms less than a hectare (EEA, 2015). The average farm size has also declined over time. Official statistics, for instance, indicate that over the past five years alone (2009/10-2013/14) the proportion of smallholders who cultivate farms less than a hectare has increased by 5.2 percent while those who cultivate farmland that vary between 1 and 2 hectares and over 2 hectares declined by 5.4 and 7.1 percent, respectively. The average wheat farmland in 2014 was only 0.34 hectares, and varies between 0.28 and 0.39 hectares. Despite such miniature plot sizes, there is high degree of inequality in access to farmlands. 57 percent of smallholder farmers cultivate only 20 percent of cultivated farmlands, whereas 46 percent of cultivated farmlands are operated only by 17 percent of farming households.

Although small-scale farmers dominate wheat production in Ethiopia, there are some large-scale commercial farms that grow wheat. However, large commercial wheat producers account only 3 to 5 percent of all wheat cultivated land (Minot et al., 2015). Wheat is the fourth largest cereal crop produced in Ethiopia (FAO, 2015a). Production of wheat has significantly increased over the past 20 years. It has increased from 890000 metric tons (MT) in the 1991/92 marketing year to 3.11 million MT in 2009/10 (Bergh et al., 2012) and to 4.04 million MT in 2014/15 (Minot et al., 2015).

There are 4.7 million wheat-producing farmers in Ethiopia. Of these, more than three-quarters (78\%) live in Oromia and Amhara regions. Southern Nations, Nationalities, and Peoples' of Ethiopia (SNNP) accounts for $13 \%$ and the Tigray region accounts for only $8 \%$. Less than $1 \%$ of the wheat farmers live in other regions of the 
country (Minot et al., 2015).

The main wheat growing areas of Ethiopia are the highlands of the central, south-eastern and northwest parts of the country. In terms of regional contribution, the production of wheat originates from Oromia $(57.4 \%)$, Amhara (27\%), SNNP (8.7\%) and Tigray (6.2\%); and more than $41 \%$ of the annual wheat production comes from only three zones in Oromia and one in Amhara regions (CSA, 2011-2013). According to ASS of 2014, there are 4.7 million wheat farmers in Ethiopia, and live in Oromia and Amhara (78\%), SNNP (13\%) Tigray $(8 \%)$ and less than $1 \%$ of wheat farmers live in other regions of Ethiopia. In the same year, the average largest wheat area per farm was $0.43 \mathrm{ha} /$ farm in Oromia region where as the smallest was recorded in SNNPs $(0.19$ ha/farm).

\subsubsection{Wheat production and Productivity in Ethiopia}

Ethiopian wheat production is expected to increase in 2019-20 but the nation will still fall short of meeting domestic needs, according to a March 29 Global Agricultural Information Network (GAIN) report from the Foreign Agricultural Service of the U.S. Department of Agriculture.

World Data Atlas reported, in 2020, wheat production for Ethiopia was 5,100 thousand tons. Before wheat production of Ethiopia started to increase to reach a level of 5,100 thousand tons in 2020, it went through a trough reaching a low of 429 thousand tons in 1977. The nation's wheat production is estimated at 4.6 million tons, up from 4.5 million tons in the previous year.

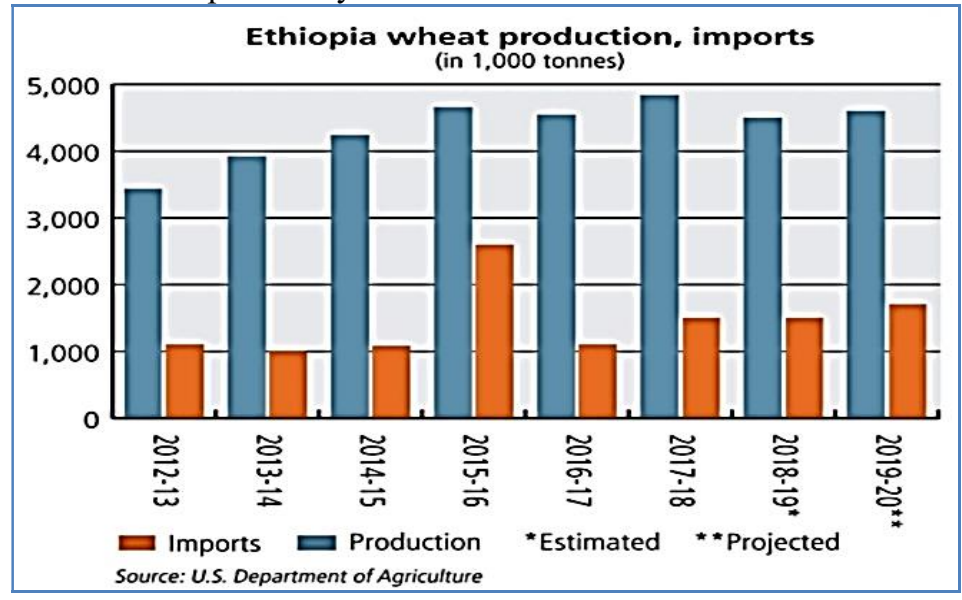

Source: https://knoema.com/atlas

Figure 1: Ethiopia wheat production and import

Wheat production in Ethiopia for $2021 / 22$ is projected to 5.18 million tons, up by 1.6 percent over the $2020 / 21$ production estimate. This is due to more GOE engagement in irrigation, better input supply, and mechanized farming in the lowland and central parts of the country. In the marketing year 2020/21, wheat production is estimated to be 5.1 million tons, which is four percent lower than the USDA estimate (USDA and GAIN, 2021).

The 2021/22 harvested area is forecast at nearly 1.9 million hectares and the wheat yield is estimated at a record 2.72 tons/hectare. The area increase over last year is because of rotating irrigated cotton land with wheat and replanting wheat in the sugarcane farms in the northern and southern lowlands. Population growth combined with the expansion of towns, and consumer changes in easy and fast-food preference increases the opportunity for wheat production as well as its marketing. Wheat production in Ethiopia is limited to smallholder farmers who use rainfed agriculture and are not able to produce enough to feed the growing population of the country, currently estimated to be more than 110 million people. Recently GOE has allocated around USD 6 million to establish agricultural machinery rental service centers in grain producing regions to build capacity and increase the efficiency of wheat producing farmers (USDA and GAIN, 2021).

In 2020, wheat yield for Ethiopia was 29,954 hg per ha. Wheat yield of Ethiopia increased from $13,259 \mathrm{hg}$ per ha in 2001 to $29,954 \mathrm{hg}$ per ha in 2020 growing at an average annual rate of $4.53 \%$. In 2019 , wheat domestic supply for Ethiopia was 6,713 thousand tons. Wheat domestic supply of Ethiopia increased from 2,201 thousand tons in 2000 to 6,713 thousand tons in 2019 growing at an average annual rate of 6.60\% (World Data Atlas, 2020). 
Table 1: Wheat area, yield, and production estimate (2016/17-2020/21)

\begin{tabular}{cccc}
\hline Year & Area(1000ha) & Production (1000MT) & Yield (ton/ha) \\
\hline $2017 / 18$ & 1600 & 4200 & 2.63 \\
$2018 / 19$ & 1750 & 4700 & 2.69 \\
$2019 / 20$ & 1800 & 4925 & 2.73 \\
$2020 / 21$ & 1850 & 5100 & 2.76 \\
\hline
\end{tabular}

Source: USDA and GAIN, 2021.

\subsubsection{Wheat producing areas in Ethiopia}

Wheat is produced in most highlands of the northern, central and south-eastern parts of Ethiopia (CSA, 2017; Demeke \& Marcantonio, 2013). This means that it can be produced in almost all regions of the country including pastoral and agro-pastoral areas like Afar, Gambela and Somali regions. However, the majority $(85 \%)$ of domestic production of wheat is grown in Oromia and Amhara regions of Ethiopia (Bergh et al., 2012). In terms of regional contribution, the production of wheat originates from Oromia (57\%), Amhara (28\%), SNNP (8.7\%) and Tigray $(6.2 \%)$ (CSA, 2013).

There are 4.7 million wheat-producing farmers in Ethiopia. Of these, more than three-quarters (78\%) live in Oromia and Amhara regions. Southern Nations, Nationalities, and Peoples' of Ethiopia (SNNP) accounts for $13 \%$ and the Tigray region accounts for only $8 \%$. Less than $1 \%$ of the wheat farmers live in other regions of the country (Minot et al., 2015).

The average wheat area per farm is also largest in Oromia regional state of the country where farmers plant an average of 0.43 ha per farm. This is the result of the existence of large farms in Bale and Arsi areas which are the main wheat growing zones of the country. That is why the two zones of the country are known as the belt of wheat production areas in Ethiopia (Bergh et al., 2012; Minot et al., 2015). In contrast, the smallest area cultivated for wheat is found in SNNP with an average of 0.19 ha per farm. The average wheat area in Amhara, Tigray and other regions is between 0.28 and 0.39 ha per farm.

We can understand that in Ethiopia wheat is mostly produced from Oromia, Amhara and SNNP regions in terms of both total production and area coverage. But, as indicated in Table 1, in terms of productivity, still the Oromia region takes the first rank, and SNNP and Amhara region take the second and the third ranks, respectively. According to CSA $(2018,2017)$ report as indicated in Table 2, from the listed potential wheatproducing regions, Amhara region shows the highest increasing trend of wheat yield (1.53 quintals per hectare) in $2017 / 2018$ production season as compared to $2016 / 2017$ production season.

Table 2: Trends of wheat production, yield and area coverage by regions between $2016 / 2017$ and $\mathbf{2 0 1 7 / 2 0 1 8}$.

\begin{tabular}{|c|c|c|c|c|c|c|}
\hline \multirow[t]{2}{*}{ Region } & \multicolumn{3}{|c|}{ 2016/2017 production season } & \multicolumn{3}{|c|}{$2017 / 2018$ production season } \\
\hline & $\begin{array}{c}\text { Area } \\
(\mathbf{1 0 0 0 h a})\end{array}$ & $\begin{array}{c}\text { Production } \\
\text { (100ton) }\end{array}$ & $\begin{array}{c}\text { Yield } \\
\text { (ton/ha) }\end{array}$ & $\begin{array}{c}\text { Area } \\
(\mathbf{1 0 0 0 h a})\end{array}$ & $\begin{array}{c}\text { Production } \\
\text { (100ton) }\end{array}$ & $\begin{array}{c}\text { Yield } \\
\text { (ton/ha) }\end{array}$ \\
\hline Oromia & 898.46 & 2664.024 & 2.965 & 898.68 & 2669.918 & 2.971 \\
\hline Amhara & 554.28 & 1319.062 & 2.380 & 554.66 & 1404.707 & 2.533 \\
\hline SNNP & 127.21 & 0.328759 & 2.5 .84 & 127.25 & 339.196 & 2.666 \\
\hline Tigray & 107.72 & 0.212867 & 1.976 & 107.93 & 214.003 & 1.983 \\
\hline Benishangul Gumuz & 2.08 & - & - & 2.46 & 5.908 & 2.406 \\
\hline
\end{tabular}

Source: CSA (2017 and 2018).

The production of wheat in the country is increasing, with fluctuation, from 2314489 in 2008 to 4537852 tons in 2016 with the average growth rate of $0.094 \%$. The yield of wheat production in the country is increasing from $16,245 \mathrm{hg}$ per ha in 2008 to $26,755 \mathrm{hg}$ per ha in 2016, growing at an average annual rate of $6.6 \%$. This growth of productivity could largely be attributed to the use of improved technologies of wheat. The minimum and maximum wheat production was recorded in 2008 and 2015. The area coverage for wheat has increased from 1.4 million hectares in $2004 / 5$ to 1.6 million hectares in 2016 , which is a growth by $14 \%$ (Table 3).

Though the area coverage, production, and productivity of wheat is increasing from time to time, its increment is in steady state and fluctuating as a result of population growth, changing food preferences and a strong urbanization trend which has led to a growing ,food gap ${ }^{\text {ee }}$ in all regions, largely met by imports, cited by Dubale A., 2019 (Macauley, 2016). The production system of most agricultural activities in the country is mixed farming system and produce under rain fed production. 
Table 3: Area harvested, production and productivity of wheat in Ethiopia (2008-2016)

\begin{tabular}{|c|c|c|c|c|c|c|}
\hline \multirow[t]{2}{*}{ Year } & \multicolumn{2}{|c|}{ Area } & \multicolumn{2}{|c|}{ Production } & \multicolumn{2}{|c|}{ Yield } \\
\hline & $\begin{array}{c}\text { Area harvested } \\
\text { (ha) }\end{array}$ & $\begin{array}{l}\text { Growth rate } \\
\text { in area }(\%)\end{array}$ & $\begin{array}{l}\text { Production } \\
\quad \text { (tons) }\end{array}$ & $\begin{array}{c}\text { Growth rate } \\
\text { in production } \\
(\%)\end{array}$ & $\begin{array}{l}\text { Yield } \\
\text { (hg/ha) }\end{array}$ & $\begin{array}{l}\text { Growth rate } \\
\text { in yield }(\%)\end{array}$ \\
\hline 2016 & 1696083 & 1.89 & 4537852 & -2.43 & 26755 & -4.25 \\
\hline 2015 & 1664565 & 0.04 & 4650934 & 9.91 & 27941 & 9.86 \\
\hline 2014 & 1663845 & 3.62 & 4231589 & 7.81 & 25433 & 4.04 \\
\hline 2013 & 1605654 & -1.35 & 3925174 & 14.28 & 24446 & 15.85 \\
\hline 2012 & 1627647 & 13.23 & 3434706 & 17.77 & 21102 & 4.01 \\
\hline 2011 & 1437485 & -7.45 & 2916334 & 2.12 & 20288 & 10.35 \\
\hline 2010 & 1553240 & -7.74 & 2855682 & -7.15 & 18385 & 0.64 \\
\hline 2009 & 1683565 & 18.17 & 3075644 & 32.89 & 18269 & 12.46 \\
\hline 2008 & 1424719 & - & 2314489 & -2.43 & 16245 & - \\
\hline Minimum & 1424719 & -7.74 & 2314489 & -7.15 & 16245 & -4.25 \\
\hline Maximum & 1696083 & 18.17 & 4650934 & 32.89 & 27941 & 15.85 \\
\hline Average & 1595200.33 & 2.55125 & 3549156 & 8.08556 & 22096 & 6.62 \\
\hline
\end{tabular}

Source: CSA, 2017, (Cited by Dubale A., 2019)

\subsection{Wheat value chain actors and their functions}

Input suppliers: Value chain analysis in agriculture starts at the input supply level. Seed, fertilizers, pesticides, and herbicides are among the production inputs supplied by the agricultural development office and private input suppliers. The major input suppliers in the wheat value chain in Duna district are Bureau of Agriculture and Natural Resource Development (BoANRD), Omo Microfinance (OMF), Areka Agricultural Research Center (AARC), cooperatives and unions and world vision Ethiopia. The survey report indicated that 65 percent of seed demand supplied through office of agricultural development. The remaining 35 percent is covered through farmer to farmer and other informal seed source. The primary cooperatives and unions play an important role in fertilizer supply through agricultural development office (Ayele et al, 2021).

Producers: In this particular study producer refers to smallholder farmers producing and marketing wheat. They play major role starting from seed bed preparation to final harvesting of the produce. Activities performed by these actors are land preparation, sowing, chemical application, cultivation and weeding, harvesting, postharvest management and transport the produce to nearest market either by using pack animals or back loading. Depending on market conditions, smallholder wheat farmers have a variety of market outlets for their product. They may sell directly to rural consumers, village collectors, primary cooperatives, and/or grain wholesalers during harvest. They can also sell to other markets directly or indirectly (Ayele et al, 2021). Dubale A., 2019 reported, producers are the main actors who participate in the production of wheat; and are the first link in the wheat market chain. Each activity in wheat producer market chain function associated with its costs, namely land preparation, planting activities, fertilizer application, weeding and harvesting.

Village collectors: These are sometimes called farm gate collectors. They are village-based middlemen who meet wheat farmers at their farm gates or along the roadside to buy freshly harvested wheat and transport it to whole salers and/or retailers in the district market (Ayele et al, 2021).

Grain wholesalers: Wholesalers are the actors who buy a large volume of wheat and its products to resell to the other next actors. They buy wheat grain mainly from individual farmers, some collectors/small traders and a few other wholesalers with in the country and sell grain to individual farmers, processors, collectors and other wholesalers (Sultan, 2016). The study of Ayele et al, 2021 in Duna District of Hadiya Zone shows that, wholesalers purchase wheat directly from producers and/or village collectors at a larger volume than any other actors. Compared to other traders, they have better storage and communication access. A study by Bergh et al. (2012), however, reported a little higher role of retailers and farmers' traders, indicating better market linkage between wheat producers and retail traders. Based on a survey conducted in 2005, they indicated that about 51 percent of wheat producers sell their wheat grain to wholesalers, whereas 43 percent of them sell to retailers and the remaining 6 percent directly to consumers.

Grain retailers: these market actors are located at the end of marketing chain, directly servicing the ultimate consumers of the marketing system (Dubale A., 2019). They perform numerous marketing functions such as buying, processing, storing, selling and other functions related to marketing. These are actors in wheat value chain who plays an important role by linking the consumers and with the product. The source of produce for these actors is either from farmers, village collectors or wholesalers and resells to consumers (Ayele et al, 2021). Flour processing factories: Wheat processer convert wheat into wheat flour and barn, flour into biscuits, pasta, macaroni and bread that add value to the product and to satisfy market requirement (Dubale A., 2019). These 
actors obtain wheat grain from grain wholesalers and co-operatives and process the grain into flour. Wheat processing factories process the grain into flour with wheat bran as a byproduct. They sell the flour either to flour wholesalers and/or retailers based on the prevailing market condition. However, the flour processing factories in Hossana town get most of their wheat grain from import through Ethiopian Grain Trade Enterprise (Ayele et al, 2021). Bergh et al. (2012) indicate that most of the millers have been operating at half-capacity due to shortage of local wheat supply.

Consumers: These are the final users of wheat products. These include household consumers, who mainly buy wheat grain from farmers and retailers, and flour from bakeries and flour retailers for their domestic consumption. The ultimate beneficiaries of the product, it has been through processed and unprocessed products. Consumers are those, who bought the wheat and its product for consumption at household level (Abdirazak, et al 2020). Consumers are those who bought wheat and its products for consumption (Dubale A., 2019).

\subsection{Wheat Value Chain Map}

The marketing channel is a trade or distribution in the process of making the product or service available for consumption. One of the most important and core for analyzing value chain system is value chain mapping. Value chain mapping means drawing of the visual representation of the value chain system. Maps identify business operations (functions), chain operators and their linkages, as well as the chain supporters within the value chain. Quantifying and describing value chains in detail includes attaching numbers to the basic chain map, e.g. numbers of actors, the volume of produce or the market shares of particular segments in the chain. Mapping market channels functions facilitates a clear understanding of the sequence of activities and the key actors and relationships involved in the value chain. Based on the analysis had been conducted, the wheat value chain presented in the following approach (Abdirazak, et al 2020).



Source: Abdirazak, et al 2020

Figure 1: Wheat Value chain Map.

\subsection{Wheat Marketing in Ethiopia}

Ethiopia remains a net importer of wheat, satisfying around 25 percent of the local demand with wheat imports. A significant share of imported wheat, mainly from the United States, comes to Ethiopia as food aid rather than commercial purchases making the country one of the largest food aid recipients in Africa. Ethiopia grain imports are almost exclusively limited to wheat. Nearly all wheat imports, except wheat donated for food and 
development aid is done through the Public Procurement and Property Disposal Service (PPPDS) under the Ministry of Finance and includes officials from the Ministry of Trade and the Ethiopian Trading and Business Corporation (ETBC). Currently, the GOE is looking to partially liberalize the wheat import market, so local millers are beginning to explore opportunities to import wheat directly with their own foreign currency sources. Millers can source wheat from the ETBC (subsidized imported wheat) or from the domestic market, with a vast disparity in the price of wheat flour. The unsubsidized price of local wheat has increased by about 40 percent in 2020/21. Currently, there are more than 600 small and large flour mills in Ethiopia, with a total production capacity of between 3 to 4 million tons of wheat flour per year. However, the mills work below 50 percent of their capacity due to wheat shortages. It is estimated that a third of these mills are in and around the country's capital, Addis Ababa. Over the past two years (2018/19-2019/20), Ethiopia imported on average 1.2 million metric tons of wheat commercially excluding the informal import of significant wheat product along the northern border and eastern part of the country (USDA and GAIN, 2021).

Table 4: Wheat and wheat product imports by country-of-origin 2019/20 (1000 MT)

\begin{tabular}{|c|c|c|}
\hline Country & Quantity (MT) & Value (USD) \\
\hline US* & 256,820 & $102,393,654$ \\
\hline Ukraine & 222,204 & $50,137,310$ \\
\hline Egypt & 61,142 & 235,3014 \\
\hline Argentine & 372,083 & $106,706,404$ \\
\hline Russia & 15,000 & $5,065,716$ \\
\hline UAE & 7,162 & $3,845,284$ \\
\hline India & 7,900 & 2,640 \\
\hline Turkey & 9,623 & $2,695,828$ \\
\hline France & 9207 & $4,464,579$ \\
\hline Sudan & 3,735 & $1,763,700$ \\
\hline Italy & 1,044 & $1,099,484$ \\
\hline Others (including informal import) & 494,080 & $144,468,992$ \\
\hline Total & $1,460,000$ & $424,996.605$ \\
\hline
\end{tabular}

Sourse: USDA and GAIN, 2021

NB: The informal import is mainly pasta (spaghetti, macaroni) and wheat flour which is converted into wheat grain equivalent. *Food Aid

\subsubsection{Marketing channel in Ethiopia}

Wheat has large number of marketing channels; it passes through different options of channels depending on the area of production and availability of infrastructures. The amount of wheat products moved from farmers to users within each channel is different. Therefore, a variation in the dominant market channel at each of the IP sites is observed. For instance, the dominant market channel in Ofla District is the direct wheat grain channel from producer to consumer sharing $58 \%$ of the volume followed by farmer to trader and final consumer sharing $33 \%$ of the volume of wheat marketed (Tadele M., et al 2018).

Each segment in the channel adds value of certain kind and it could be form value, spatial/transportation value and storage/time value. For instance, traders add both spatial and time value in that they transport wheat from far off location to urban centers. They also add time value by making aggregation and storage of wheat for a while and then supply to markets in later seasons. On the other hand, millers add form values by changing wheat grain to flour. Bakeries also add form values by changing wheat flour into bread, biscuits, and other products.

It was reportedly mentioned that there is a little room for direct marketing between producers and millers, and hence farmers are mainly price takers. There were some market related problems identified in the study sites. These identified problems included limited experience of sorting, grading, and cleaning wheat grain to assure the quality for good end wheat products such as bread, pastry, and cake.

Farmers often tend to bring wheat to markets mixed with impurities and even grain of varying sizes, such as shriveled ones. The other problem was that units for selling wheat are often local and not standardized ones making farmers disadvantaged. In general, assessment of the prevailing marketing channels of wheat products such as grain, flour, and bread would help to understand the type of value addition made on wheat and plan for possible interventions that help promote further value addition and create more sustainable demands for wheat. It would help us ensure and illustrate a reliable potential opportunity to enhance wheat production (Tadele M., et al 2018).

Marketing channel is a business structure of interdependent organizations involved in the process of making the product or service available for consumption starting from product origin (Kotler and Armstrong, 2003). It is important to provide a systematic information/knowledge about the flow of goods and services starting from production to final destination. Different scholar"s results showed that the marketing channels of wheat looks 
like the following: The identified ten different wheat marketing channels are listed below as follows

Channel 1: Producer $\rightarrow$ Consumer

Channel 2: Producer $\rightarrow$ Retailer $\rightarrow$ Consumer

Channel 3: Producer $\rightarrow$ Assembler $\rightarrow$ Retailer $\rightarrow$ Consumers

Channel 4: producer $\rightarrow$ Assembler $\rightarrow$ Wholesaler $\rightarrow$ Processors $\rightarrow$ Consumers

Channel 5: producer $\rightarrow$ Assembler $\rightarrow$ Wholesaler $\rightarrow$ Retailer $\rightarrow$ Consumers
Channel 5: producer $\rightarrow$ Assembler $\rightarrow$ Wholesaler $\rightarrow$ Retailer $\rightarrow$ Consumers

Channel 6: producer $\rightarrow$ Wholesaler $\rightarrow$ Retailer $\rightarrow$ Consumers

Channel 7: Producer $\rightarrow$ Wholesaler $\rightarrow$ Processor $\rightarrow$ Consumers

Channel 8: Producer $\rightarrow$ Wholesalers $\rightarrow$ Processors $\rightarrow$ Retailers $\rightarrow$ Consumers

Channel 9: Producer $\rightarrow$ Cooperatives $\rightarrow$ Processors $\rightarrow$ Consumers
Channel 10: Producer $\rightarrow$ Cooperatives $\rightarrow$ Wholesalers $\rightarrow$ Retailers $\rightarrow$ Consumers

Channel 11: Producer $\rightarrow$ Cooperatives $\rightarrow$ Wholesalers $\rightarrow$ Processors $\rightarrow$ Consumers

Source: Ashenafi, 2010; Mohammed, 2011; Sultan, 2016

SWOT analysis of wheat marketing segment

Table 5 presents the strengths, weakness, opportunities, and threats of wheat marketing segment

Table 5: SWOT analysis of wheat marketing segment

\section{Strengths}

- Favorable infrastructure to facilitate trading of wheat across the country, such as transportation, communication and others.

O Options of marketing channels in place through which producers and traders can exchange

- Government imports of wheat to bridge-up the supply and demand gaps, and stabilize the likely mounting of wheat price

Weaknesses

- Limited market integration between supply and demand areas

- Supply of ungraded and unsorted wheat produce to markets and processing sectors

- Intermittent wheat supply that may leading to unpredictable price fluctuation

- limited wheat traders in areas of low wheat production

Source: Tadele M., et al 2018

\subsection{Major Opportunities and Challenges in Wheat Value Chain}

\subsubsection{Opportunity in Wheat Value Chain}

There are many opportunities for the wheat value chains actors in the area. The potential marketing opportunities of the area are the buildup of good road that connects market to different towns in the country which creates potential demand for the products produced in the area. Furthermore, the increasing food processing plants in and around the area is creating additional demand for the Wheat commodities. Consequently, this contributes for commercialization of rural economy and creates many off-farm jobs opportunities. Furthermore, provision of infrastructure facilities like telecommunication, power supply and financial institutions (Banks, Micro-Finance) 
supports the marketing activities in the area.

The interest of farmers in improved varieties; the availability of market for the crop; strong interest of national and international research organizations in the wheat improvement; the importance of the crop in food self-sufficiency as strategic crop at regional and national levels; the diverse use value of the crop; availability of various processing plants for various products; and availability of human resource and knowledge in the improvement and development of the crop are some of the major opportunities available for the crop improvement and expansion of its production in the area.

\subsubsection{Challenges in Wheat Value Chain}

Factor affecting wheat production and marketing sector takes into account the systematic understanding of the problems that exist across the value chain from input supply to marketing of the final product which affects value addition at different stages. Major wheat production constraints include; diseases, weeds, low soil fertility, shortage of improved seed variety, less farmers awareness of improved crop management practices, high cost of combine harvesting since the area wheat produce farmers follow mechanized wheat production system, less availability and efficacy of many pesticides available in the market, untimely supply of fertilizers and shortage of capital to buy farm inputs and high price of seeds, chemical fertilizers and pesticides were the factors that affected production and productivity of wheat in the area. There are also quality problem due to poor weeding and inferior harvest management techniques. In addition to this, rain during the harvesting period sometimes spoils large volumes of grains. The small scale farmer does not have an insurance mechanism that safeguards its harvest from natural hazards, such as unwanted rain.

The major marketing constraints faced the farmers and traders is unfair pricing and cheating of traders on balance; lack of timely and sufficient market information; lack of credit, market infrastructure and transportation cost; low price of commodities at harvest time; weak market linkages among value chain actors and less bargaining power of farmers in the market. There are also regular market fluctuations, different quality problems and shortage of storage facilities in addition to poor transportation. Processors main challenges were lack of uniformity in quality of flour for bread, cakes and cookies all which do not have standards established for them. There are also high production costs relative to selling price, unstable prices of flour, unfair competition from illegal traders and finally frequent electric power and water interruptions were also the main constraint. Due to the above problems farmers supply different quality products to actors involved in wheat business in the area.

\section{Conclusion and Recommendations}

\subsection{Conclusion}

In Ethiopia, agriculture contributes over 35.8 percent to the national gross domestic product (GDP), almost 90 percent of export and 72.7percent of employment (CIA, 2018). Ethiopia is the second largest wheat producers in Sub Saharan Africa next to South Africa, with a potential expansion to 1.3 million hectare.

The main participants in wheat value chain are categorized as direct/main actors (actors who are directly participated in the market chain) and indirect/supportive actors (actors who provide supports to the main actors either financially or none-financially). The main actors in the chain include producers, processor, assembler, wholesaler, retailers, consumers whereas the indirect actors are financial institutions, governments, NGOs (KIT, 2008; Solomon et al. 2017).

Wheat has large number of marketing channels; it passes through different options of channels depending on the area of production and availability of infrastructures. The amount of wheat products moved from farmers to users within each channel is different. They also add time value by making aggregation and storage of wheat for a while and then supply to markets in later seasons. On the other hand, millers add form values by changing wheat grain to flour (Tadele M., et al.2018).

There are many opportunities for the wheat value chains actors in the area. The potential marketing opportunities of the area are the buildup of good road that connects market to different towns in the country. Consequently, this contributes for commercialization of rural economy and creates many off-farm jobs opportunities. Furthermore, provision of infrastructure facilities like telecommunication, power supply and financial institutions (Banks, Micro-Finance) supports the marketing activities in the area. On the other hand in wheat value chain Low input availability, Diseases, weeds, low soil fertility, less farmers awareness of improved crop management practices, low price of commodities at harvest time, less bargaining power of farmers in the market, Poor infrastructures and transportation cost, lack of timely and sufficient market information, weak market linkages among value chain actors, Lack of quantity and quality, Lack of capacity and packaging materials are some of the main constraints in wheat value chain actors.

This review revealed that the majority of farmers involved in wheat production are small scale farmers. Wheat marketing sector takes two categories, the domestic and international market. The processing segment is operating by far below their capacity mainly due to shortage of wheat grain followed by electric power. A permanent increase in domestic wheat consumption due to population increase and changes in life style resulted in rises in the prices of wheat products. These show that there is a weak linkage among the wheat value chain 
actors in Ethiopia. One of the indicators for this weak linkage is the absence (very low level) of linkage between producers and millers few of the wheat produced is directly sold to millers.

\subsection{Recommendations}

From the above wheat value chain analysis, the following recommendation are forwarding to concerned body;

Improvement of access to credit for wheat market participants: many traders and farmers are not entering the wheat market because of the absence of enough initial capital and collaterals. Therefore, the credit access should be improved to enable them to participate in the market.

Improving access to wheat market information and infrastructure: having market information plays a great role in improving the efficiency and effectiveness of wheat market chain. But, many farmers do not have market information. Therefore, facilitating and improving the quality and types of market information delivery used by farmers shall take policy attention. In addition to this due to lack of market infrastructure, wheat producer farmers are not participating in the market. Therefore, the government should build market infrastructure to improve the marketing and marketing system of wheat in the areas as well in the country.

Strengthening the extension service: Access to extension services affect the probability of participants in value addition and participation as well fair utilization from the chain. It also enables flow of information and transfer of knowledge and scientific findings to practice that will help all actor especially small holder farmers in production of value added products. Therefore, strengthening agricultural extension services should be considered as important input for producing value added products and help to penetrating producer in the market system.

Providing training service and Enhance wheat producer bargaining power: The enhancement of wheat producers' bargaining power through cooperatives is the best measure that should target increasing farmer's share of benefit from his marketable produce. In order to solve shortage of improved varieties seed, improving farmers' knowledge in quality seed production through training is important.

\section{REFERENCES}

Abdirazak Abdala Ulisido, Alemayehu Abebe. Analysis of Wheat Value Chain in Denaba Kebele, Dodola Districts West Arsi Zone, Oromia Region, Ethiopia. International Journal of Food Engineering and Technology. Vol. 4, No. 2, 2020, pp. 36-45. doi: 10.11648/j.ijfet.20200402.15

Abu Tefera. 2012. Grain and Feed Annual Report: Ethiopia. USDA Global Agricultural Services: Global Agricultural Information Network (GAIN). Report Number: ET 120.

AGRA. (2018). Africa agriculture status report: Catalyzing government capacity to drive agricultural transformation (Issue 6). Anne Marie Nyamu, Editorial, Publishing and Training Consultant.

Assefa Ayele, , Tessema Erchafo, Alemayehu Bashe and Seyfu Tesfayohannes (2021) Value chain analysis of wheat in Duna district, Hadiya zone, Southern Ethiopia, Heliyon $7 \quad$ (2021) e07597https://doi.org/10.1016/j.heliyon.2021.e07597

CSA, 2018. Agricultural Sample Survey 2017/2018; Report on Area and Production of Major Crops, I. CSA, Addis Ababa.

CSA (Central Statistical Agency of Ethiopia), 2017. Agricultural Sample Survey. Report on Area and Production of Major Crops.

CSA (Central Statistical Agency). 2015. Report on Area and Production of Major Cereals (Private Peasant Holdings, Meher Season). Agricultural Sample Survey 2014/15 (2007 E.C), Volume III. Addis Ababa, Ethiopia.

CSA (Central Statistical Agency) (2014a). Agricultural Sample Survey 2013/14. Volume I: Report on Area and Production of Major Crops. Addis Ababa.

CSA. (2014). Agricultural sample survey report on area and production of major crops. Statistical Bulletin Volume VI

CSA. (2013). Agricultural sample survey report on area and production of major crops (Private peasant holdings, Meher season 2012/2013 (2005 E.C.)). The FDRE statistical bulletin, Volume 1.

CSA. (2012). Agricultural sample survey report on area and production of major crops (Private peasant holdings, Meher season 2011/2012 (2005 E.C.)). The FDRE statistical bulletin, Volume VII.

Demeke, M., Di, F. 2013. Analysis of incentives and disincentives for wheat in Ethiopia. Technical notes series, MAFAP, FAO, Rome. Available at www.fao.org/mafap.

Dubale Abate, 2018. Review on Market Chain Analysis of Wheat in Ethiopia. Department of Agribusiness and value chain management, Wolkite University, Wolkite, Ethiopia

EEA (Ethiopian Economics Association). (2015). Report on the Ethiopian Economy. Ethiopian Economics Association, Addis Ababa, Ethiopia.

FAOSTAT. 2015. [Online] available at http://faostat.fao.org.

FAO (Food and Agriculture Organization) (2015a). Food Balance Sheets. FAOSTAT. Rome. 
FAO, 2009. Agricultural commodities: profiles and relevant WTO negotiating issues, 2009. Retrieved fromhttp://www.fao.org/docrep/006/y4343e/y4343e02.htm\#TopOfPage.).

Falola, A., Achem, B. A., Oloyede, W. O. and Olawuyi, G. O., 2017. Determinants of Commercial Production of Wheat In Nigeria: A Case Study Of Bakura Local Government Area,Zamfara State. Trakia Journal of Sciences, 15 (4).

Gebre-Madhin, Z. E., 2004. Market Institutions, Transaction Costs, and Social Capital in the Ethiopian Grain Market, International Food Policy Research Institute Washington, D.C Research Report 124

Gugerty, M.K., Bergh, K., Anderson, C.L. and Chew, A., 2012. Wheat value chain: Ethiopia.

Kirimi, L. Sitko, N., Jayne, T. S., Karin F., Muyanga M., Sheahan, M., Flock J., and Bo, G. (2011). Farm Gateto-Consumer Value Chain Analysis of Kenya's Maize Marketing System. Tegemeo Institute of Agricultural Policy and Development, Nairobi, Kenya.

Minot, N., Warner, J., Lemma, S., Kassa, L., Gashaw, A., and Rashid, S. (2015). The Wheat Supply Chain in Ethiopia: Patterns, Trends, and Policy Options. International Food Policy Research Institute (IFPRI) Washington, DC.

Mohammed H. (2009). Value Chain Concept and Its Application to Wheat in ethiopia. Paper presented at Value Chain Seminar for Developing Rural Agri-Business in Ethiopia. UNECA Conference Centre, 24 November 2009, Addis Ababa, Ethiopia.

Najafi, A. 2014. Wheat production price performance prediction in the Iranian north province. African Journal of Agricultural Research, 9 (1), 74-79.

Sultan Usman, 2016. Analysis of Wheat Value Chain: The case of Sinana district, Bale Zone, Oromia region,Ethiopia. Thesis Haramaya University, Haramaya, Ethiopia.

Tadele Mamo, Wudineh Getahun, Agajie Tesfaye, Tesfaye Solomon, Ali Chebil, and Tolessa Debele (2018). Wheat Value Chain Analysis: The Case of Innovation Platform Sites of SARD-SC Wheat Project. EIAR. Addis ababa, Ethiopia.

USDA (United States Department of Agriculture). 2014. Ethiopia. Grain and Feed Annual, Agrocharts News, Apr 2014. Available online at agrocharts.

Walker, D.J. and Wandschneider, T. 2005. Local Food Aid Procurement in Ethiopia. Case Study Report by Natural Resources Institute for EC-PREP, UK Department for International Development.

World Data Atlas (2020). https://knoema.com/atlas 